Plant Biotechnology Persa https://pbp.medilam.ac.ir

\title{
Sedation with Medicinal Plants: A Review of Medicinal Plants with Sedative Properties in Iranian Ethnoblotanical Documents
}

\section{Fariba Bahmani ${ }^{1}$, Hamidreza Kazemeini ${ }^{2}$, Fatemeh Hoseinzadeh-Chahkandak ${ }^{3}$, Tahereh Farkhondeh $^{4 *}$, Mahshid Sedaghat ${ }^{5}$}

\author{
${ }^{1}$ Shohada Hospital, Dehloran City, Ilam University of Medical Sciences, Ilam, Iran
${ }^{2}$ Assistant Professor, Department of Food Hygiene, Faculty of Veterinary Medicine, Amol University of Special Modern Technologies, Amol, Iran

${ }^{3}$ Social Determinants of Health Research Center, Birjand University of Medical Sciences, Birjand, Iran
${ }^{4}$ Cardiovascular Diseases Research Center, Birjand University of Medical Sciences, Birjand, Iran
${ }^{5}$ Faculty of Medicine, Birjand University of Medical Sciences, Birjand, Iran

Article Info

*Correspondence to:

Tahereh Farkhondeh

farkhondeh2324@gmail.com

Article History:

Received: 11 August 2019

Accepted: 18 Oct 2019

ePublished: : 20 Nov 2019

Keywords: Sedative, Medicinal plants,

Ethnobotany, Iran

\section{Abstract}

The complexity of today's modern society, increasing problems and changes in lifestyles can lead all to stress and anxiety. To control stress and anxiety, sedative drugs that have anxiolytic and sedative effects and temporarily calm the person and lead to a pleasant sleep are used. However, it must also be kept in mind that each of these drugs have their own side effects. The information in this review study was obtained from scientific publications indexed in databases such as the Information Sciences Institute, PubMed, Scopus, Scientific Information Database, Magiran, and Google Scholar that were retrieved by using relevant search terms including sedative, ethnobotany, herbal drug, Iran, medicinal plants, extracts, and essential oils. A total of 46 articles were retrieved by our initial search. The articles were reviewed. Forty three articles were further reviewed, 16 of which were finally used to review the sedative effects in ethnobotany. Being sedative is one of the reported properties of some herbal drugs. The use of these materials can be beneficial and will not cause side effects like those of conventional sedative drugs. The use of oral herbal drugs is one of the ancient methods that have been used to control anxiety, stress and pain. Besides, numerous side effects of chemical drugs

Copyright (C) 2020 The Author(s). This is an open-access article distributed under the terms of the Creative Commons Attribution License (http://creativecommons.org/licenses/by/4.0), which permits unrestricted use, distribution, and reproduction in any medium, provided the original work is properly cited. 
have caused a renewed tendency to use herbal medicine. Therefore, this study is aimed to introduce some of the most effective medicinal plants with sedative properties based on Iranian ethnobotanical documents.

How to cite this paper

Bahmani F, Kazemeini HR, Hoseinzadeh-Chahkandak F, Farkhondeh T, Sedaghat M. Sedation with medicinal plants: A review of medicinal plants with sedative properties in Iranian ethnoblotanical documents. Plant Biotechnology Persa $2019 ; 1(1): 13-24$.

\section{Introduction}

The complexity of today's modern society, increasing problems, and changes in lifestyles can lead to stress, anxiety and mental disorders in people that have become the most important problems in modern societies [1-5]. Stress is defined according to mental perceptions of an individual and his/her perception of a situation as being beyond his/her abilities that can disturb his/her health. In general, stress is experienced by all people and it should be noted that certain degrees of the stress can be effective in increasing and improving the performance of individuals, but when stress exceeds the capacity of a person, behavioral and emotional disorders occur in him/her [6,7]. Anxiety is a type of natural feeling that is experienced in threatening situations. Clinical properties of anxiety disorders are the same as normal anxiety and do not differ in type, but do in duration and severity [8]. Mental state, anxiety and concern are accompanied by certain physiological changes such as increased heart rate, hypertension, increased respiratory rate, and increased muscle tone, making the individual ready for escape or defense [9]. Pathologic anxiety is one of the most common psychiatric disorders that cause disturbance of daily life and suffering in humans. Benzodiazepines and barbiturates are used to treat this condition [10]. Sedatives are drugs that, by suppressing the central nervous system (CNS), can lead to calmness, relaxation of the nervous system, relief of anxiety and stress, sleepiness, euphoria, decrease in respiratory rate, sensations of imbalance, muscle relaxation, impaired judgments, and slow and hesitant reactions $[11,12]$. Although taking chemical medications to relieve anxiety can temporarily calm the person and bring about a pleasant sleep for him/her, it must also be kept in mind that each of these medications have their own side effects, and it is therefore advised to take them according to the prescription of a physician and not to take them at high doses under any circumstances [11]. Sedatives have anxiolytic and calming effects and are also used to treat insomnia. Common sedative medications include benzodiazepines, opiates, barbiturates and hypnotics. Opiates are one of the most sought-after drug classes because of causing analgesia. In addition to analgesia, these drugs also have sedative effects $[13,14]$. Side effects of sedatives, especially in the elderly, are due to hypersensitivity to these drugs, which can lead to certain complications such as weakened response of the nervous system to hypercapnia, hypoxia, hypotension that should be treated, and postoperative apnea [15-18]. Medicinal plants and foods have a huge impact on the health of individuals $[19,20]$. Any food has a specific impact on the function of the body. Being sedative is one of the reported properties of some herbal drugs. They are very beneficial and less likely to cause the side effects of conventional sedative drugs. The use of oral herbal drugs is one of the ancient methods that have been used to control anxiety, stress and pain. In addition, several side 
effects due to chemical drugs have caused a renewed tendency to using herbal medicine [21]. Medicinal plants have been shown to boost the immune system, produce antimicrobial effects, and be effective on infectious and non-infectious diseases and chronic diseases, which have been proven in both ethnobotanical and pharmacological studies [22-27]. Therefore, this study is aimed to introduce some of the most effective medicinal plants with sedative properties based on Iranian ethnobotanical documents.

\section{Methodology}

The information in this review study was obtained from scientific publications indexed in databases such as the Information Sciences Institute, PubMed, Scopus, Scientific Information Database, Magiran, and Google Scholar that were retrieved by using relevant search terms including sedative, ethno-botany, herbal drug, Iran, medicinal plants, extracts, and essential oils. A total of 46 articles were retrieved by our initial search. The articles were reviewed. Forty three articles were further reviewed, 16 of which were finally used to review the sedative effects in ethno-botany.

\section{Results}

Ethnobotany is the study of how people of a particular ethnic group, culture, or region use indigenous plants. The results of this review of Iranian ethnobotanical documents showed that medicinal plants from certain families such as Apiaceae, Asteraceae and Lamiaceae are among the most important plants used in Iran for their sedative effects (Table $1)$.

The geographical map of Iran is shown in Figure 1.

Figure 1. Geographical map of Iran

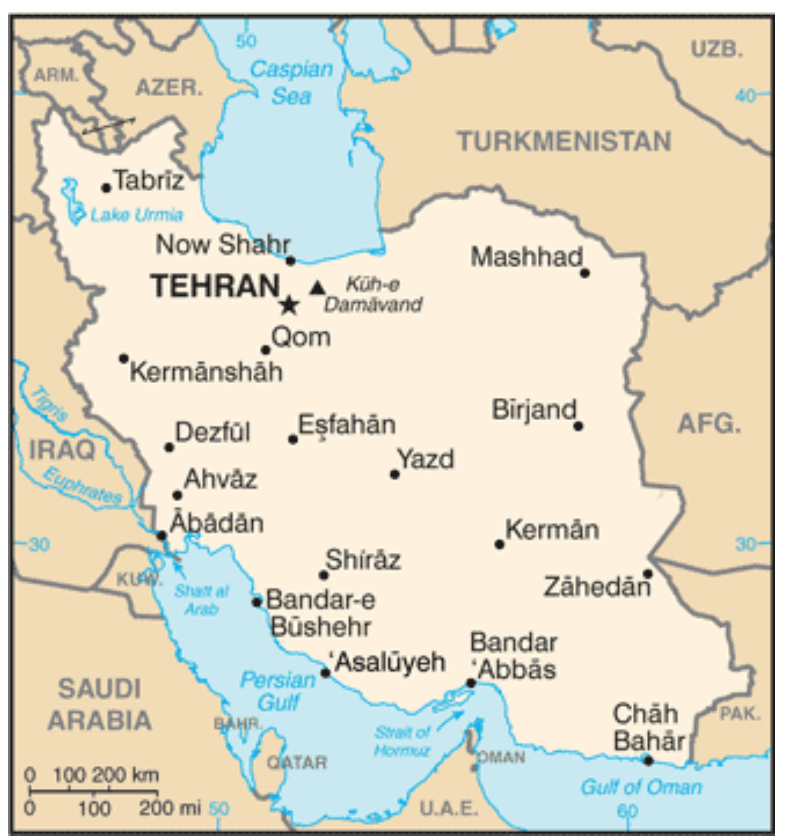

Table 1. Medicinal plants with sedative effects according to Iranian ethnobotanical documents

\begin{tabular}{|l|l|l|l|l|}
\hline Scientific name & Family name & Domestic name & Used organs & Region \\
\hline Allium sp & Liliaceae & Paiz vahshi & Bulb & Abadeh fars [28] \\
\hline Nonnea cospica & Boraginaceae & Chesh gorbei & Flower & Joupar kerman [29] \\
\hline Valeriana ficariaefolia & Valerianaceae & Alafe gorbeh & Root, rizhome & Joupar kerman [29] \\
\hline Avena sativa & Poaceae & Jo dosar & Aerial parts & Zabol [30] \\
\hline Rubia tinctorum & Rubiaceae & Ronas & Root & Zabol [30] \\
\hline Heracleum persicum & Apiaceae & Golpar & Fruit and leaf & Khuzistan [31] \\
\hline Kelussia odoratissima & Apiaceae & Karafseh kouhi & Aerial parts & Khuzistan [31] \\
\hline
\end{tabular}




\begin{tabular}{|c|c|c|c|c|}
\hline Pimpinella anisum & Apiaceae & Anison & Fruit & Khuzistan [31] \\
\hline Trachyspermum copticum & Apiaceae & Zenian & Fruit and seed & Khuzistan [31] \\
\hline Centurea depressa & Asteraceae & Gole gandom & Stem & Khuzistan [31] \\
\hline Lactuca virosa & Asteraceae & Kahoye vahshi & Aerial parts & Khuzistan [31] \\
\hline Echium amoenum & Boraginaceae & Gav zaban & Flower & Khuzistan [31] \\
\hline Brassica napus & Brassicaceae & Shalgham & Seed and root & Khuzistan [31] \\
\hline Humulus lupulus & Cannabaceae & Razak & Inflorescence & Khuzistan [31] \\
\hline Lavandula angustifolia & Lamiaceae & Ostokhodous & $\begin{array}{l}\text { Flower, stem } \\
\text { and leaf }\end{array}$ & Khuzistan [31] \\
\hline Melissa officinalis & Lamiaceae & Badranjbouyeh & Leaf and stem & Khuzistan [31] \\
\hline Mentha longifolia & Lamiaceae & Pouneh & $\begin{array}{l}\text { Leaf and stem } \\
\text { and flower }\end{array}$ & Khuzistan [31] \\
\hline Scutelaria lateviflora & Lamiaceae & Varangbou & Seed & Khuzistan [31] \\
\hline Peganumharmala & Nitrariaceae & Spand & Seed and fruit & Khuzistan [31] \\
\hline Crataegus curvisepala & Rosaceae & Zalzalak & $\begin{array}{l}\text { Leaves, flowers } \\
\text { and fruits }\end{array}$ & Khuzistan [31] \\
\hline Hyoscyamus orthocarpus & Solanaceae & Bazrolbanj & Leaf and seed & Khuzistan [31] \\
\hline Pistacia khinjuk & Anacardiaceae & Pesteh kouhi & Fruit & Fasa [32] \\
\hline Avenasativa & Graminaceae & Jodosaar & Fruit & Fasa [32] \\
\hline Stachysinfllata & Lamiaceae & $\begin{array}{l}\text { Sonboleh } \\
\text { badkonaki }\end{array}$ & $\begin{array}{l}\text { Flowered } \\
\text { flower }\end{array}$ & Fasa [32] \\
\hline Alliumcanadense & Liliaceae & Sirmouk & Aerial parts & Fasa [32] \\
\hline Papaverdubium & Papaveraceae & Shaghayegh & Flower \& Gum & Fasa [32] \\
\hline Plantagomajor & Plantaginaceae & Barhang & Seed and leaf & Fasa [32] \\
\hline Citrusaurantium & Rutaceae & Naranj & $\begin{array}{l}\text { Flower and } \\
\text { fruit }\end{array}$ & Fasa [32] \\
\hline Marrubium vulgare & Labiatae & Ferasion & Stem and leaf & Gichak [32] \\
\hline Zataria multiflora & Lamiaceae & Abeshm & Aerial parts & Naein [33] \\
\hline Ziziphora tenuior & Lamiaceae & Ostaghodos & Aerial parts & Naein [34] \\
\hline Echium spp. & Boraginaceae & Gavzaban & Flower & Erim neka [35] \\
\hline Viola ororata & Violaceae & Banafsheh & Flower & Erim neka [35] \\
\hline Achillea biebersteinii & Asteraceae & Boumadaran & $\begin{array}{l}\text { Leaf } \\
\text { flower }\end{array}$ & Dehloran and Abdanan [36] \\
\hline
\end{tabular}


Bahmani F et al

\begin{tabular}{|c|c|c|c|c|}
\hline Cerasus microcarpa & Rosaceae & Albalouyeh vahshi & Resin & Dehloran and Abdanan [36] \\
\hline Hypericum scabrum & Hypericaceae & Gole raei & $\begin{array}{l}\text { Flowered } \\
\text { flower }\end{array}$ & Dehloran and Abdanan [36] \\
\hline Lonicera nummulariifolia & Caprifoliaceae & Pilakhor & $\begin{array}{l}\text { Leaf and } \\
\text { flower }\end{array}$ & Dehloran and Abdanan [36] \\
\hline Narcissus tazetta & Amaryllidacea & Narges & Flower & Dehloran and Abdanan [36] \\
\hline Papaver dubium & Papaveraceae & Khashkhash tanaz & $\begin{array}{l}\text { Leaf and } \\
\text { flower }\end{array}$ & Dehloran and Abdanan [36] \\
\hline Stachys lavandulifolia & Lamiaceae & Sonbolei & $\begin{array}{l}\text { Leaf and } \\
\text { flower }\end{array}$ & Dehloran and Abdanan [36] \\
\hline Grammosciadium platycarpum & Apiaceae & Shevid kouhi & Aerial parts & Behbahan [37] \\
\hline Anthemis cotula & Apiaceae & Babouneh bahari & Aerial parts & Behbahan [37] \\
\hline Leonurus cardiaca & Lamiaceae & $\begin{array}{l}\text { Ostoghodous } \\
\text { vahshi }\end{array}$ & Aerial parts & Behbahan [37] \\
\hline Mentha mozaffarianii & Lamiaceae & Pouneh kouhi & Aerial parts & Behbahan [37] \\
\hline Datura stramonium & Solanaceae & Tatoureh & Aerial parts & Behbahan [37] \\
\hline Celtis australis & Ulmaceae & Daghdaghan & Aerial parts & Behbahan [37] \\
\hline Vitex pseudonegundo & Verbenaceae & Panj angosht & Aerial parts & Behbahan [37] \\
\hline Verbenaceae & Verbenaceae & Gole gavzaban & Aerial parts & Razovergolan [38] \\
\hline Cannabis sativa & Cannabaceae & Shahdaneh & Leaf, seed & Sirjan [39] \\
\hline Echium amoenum & Boraginaceae & Zabangav & Aerial parts & Sirjan [39] \\
\hline Datura innoxia & Solanaceae & Datoureh & Stem & Sistan [40] \\
\hline Solanumnigrum & Solanaceae & Tajrizi siah & Leaf and seed & Sistan [40] \\
\hline Borago officinalis & Boraginaceae & Sisenak & $\begin{array}{l}\text { Flower and } \\
\text { leaf }\end{array}$ & North Iran [41] \\
\hline Hyoscyamus niger & Solanaceae & Taltouleh & Leaf & North Iran [41] \\
\hline Melissa officinalis & Lamiaceae & Badranjbouyeh & Aerial parts & Kazeroun $[42]$ \\
\hline Vitex agnus-castus & Verbenaceae & Bangela & Leaf and fruit & Hormozgam [43] \\
\hline
\end{tabular}


every man and woman, old and young, and even children and adolescents. Relaxation or mild anesthesia is a method that reduces the amount of pain and incitement caused by the therapeutic process or painful diagnosis using sedative medications. Drugs that are used in this process include Propofol, Probiotics, Ketamine, Fentanyl, and Midazolam [44]. Over the years, natural medicines, especially medicinal herbs, have been the basis and sometimes even the only remedy, while raw materials used in the pharmaceutical industry were used [45]. Today, due to the adverse effects of some chemical drugs and people's beliefs about the increased safety of the use of natural compounds, the tendency to use herbal medicines has increased. One of the problems that is spreading among our society today is insomnia and neurotic stress caused by personal and social problems. This has led people to tend to use sedative medications.

Among the others, the most effective plants with sedative hypnotic properties are Valeriana officinalis. It is noted as a remedy to modulate the troubled nerves and to induce untroubled sleep. It has mild effects, however, it is a safe remedy for use [46]. Valeriana officinalis is prepared as ethanol or aqueous extracts. Its therapeutic dose is about 600 mg per day. The mechanism action of $V$. officinalis has been roughly identified previously. However, the plant has more than 100 components and it is not known which one is responsible for its anxiolytic action [47]. Valeric and isovaleric acids are among the most important components and have GABA re-uptake inhibitory in brain, which are involved in its tranquilizer effects. Valerian preparations of usually do not impose immediate action and usually 2 to 4 weeks is necessary for achievement significant improvements [48]. The main value of this plant is its capability of promoting natural sleep. However, this will be achieved after several weeks consumption of this remedy. It has no adverse health effects or risk of dependence [49]. Echium amoenum is another plant which possess sedative effects. Chemical substances such as flavonoids, saponins and unsaturated terpenoids and sterols has been identified in Echium amoenum. Natural Flavonoids and their derivatives maintain mild sedative and anxiolytic effects via binding to the central benzodiazepine receptors [50]. Infusion of hydroalcoholic and aqueous extracts of Echium amoenum in mice have been reported to induce anxiolytic activities [51]. Furthermore, it has been showed that administration of $50 \mathrm{mg} / \mathrm{kg}$ of Echium amoenum extract induces anxiolytic effects and a reduction in locomotor activity [52]. Another noteworthy plant to mention is humulus lupus. It is used in conditions such as insomnia and anxiety. Humulus lupus extracts contain alpha bitter acids and beta acids which both have sedative effects, but the latter is weaker compared to the first one. Humulus lupus interacts with melatonin receptors which play a role in sleep [53]. In a study by shishehgar et al. 2012, it was showed that humulus lupulus had more sedation, pre-anesthetic, and anti-anxiety effect compared to diazepam [54]. It should be noted that high level of free radicals, which usually lead to oxidative stress and neurodegenerative disorders and health complaints. Patients with primary insomnia have been shown to possess significantly lower glutathione activity and higher amount of blood malondialdehyde than normal subjects which show that insomnia increases oxidative stress and sleep can reduce oxidative stress [55]. The plants presented in this review and a lot of other plants have antioxidant activities [56-58]. Therefore, these plants may also show positive effects on insomnia. It is important to note that most of plants have multi-function [59-61].

\section{Conclusion}

The use of oral herbal drugs is one of the ancient methods that have been used to control anxiety, stress and pain. Besides, numerous side effects of chemical drugs have caused 
a renewed tendency to using herbal medicine. Therefore, this study is aimed to introduce some of the most effective medicinal plants with sedative properties based on Iranian ethnobotanical documents.

\section{Conflict of interest}

None of the authors have any conflict of interest to declare.

\section{Consent for publications}

All authors approved the final manuscript for publication.

\section{Availability of data and material}

Data are available on request from the authors.

\section{Funding/Support}

None

\section{References}

1. Bhui K, Fletcher A.Common mood and anxiety states: gender differences in the protective effect of physical activity. Soc Psychiatry Psychiatr Epidemiol 2000; 35(1):28-35.

2. Valizadeh R, Veisani Y, Delpisheh A, Kikhavani S, Sohrabnejad A. Major depression and psychiatric disorders in Iranian prisoners based on a clinical interview: A systematic review and meta-analysis. Shiraz E Med J 2017; 18(6):44979.

3. Mohammadalizadeh Charandabi S, Rezaei,N, Hakimi S, Khatami SH, valizadeh $\mathrm{R}$, Azadi A. Sleep disturbances and sexual function among men aged 4575 years in an urban area of Iran. Sleep Sci 2016; 9(1): $29-34$.

4. Valizadeh R, Sarokhani D, Sarokhani M, Sayehmiri K, Ostovar R, Angh P, Malekzadeh M. A study of prevalence of anxiety in Iran: Systematic review and meta-analysis. Der Pharma Chemica 2016; 8(21): 4857.

5. Motl RW, Birnbaum AS, Kubik MY, Dishman RK. Naturally occurring changes in physical activity are inversely related to depressive symptoms during early adolescence. Psychosom Med 2004; 66: 336-342.

6. Pourghane P, Sharif azar E, Zaer sabet F and Khorsandi M. Survey the effect of religious beliefs in stress reduction in students of Langroud Faculty of Medical Sciences. Guilan Uni Med Sci J 2011; 20 (63): 10-5.

7. Hakimgavadi $M$, Lavasani $M$, Haghighatgoo $M$ and Zebardast O. Relation of depression,anxiety, stress and personality trait in dedicated,s children. Veteran Med J 2011; 3 (9): 9 - 16.

8. Whsam KE. Antioxidant activity in extracts from coriander. Food Chem 2004; 88 (2): 293-7.

9. Linden C. Anxiety and Panic Attacks Solution: Reprogramming your anxiety with the Linden Method. Available from: http://www.Lindenmethod.com

10. Finn DA, Rutledge-Gorman MT, Crabbe JC. Genetic animal models of anxiety. Neurogenetics 2003; $4(3): 109-35$.

11. Sadock BJ, Sadock VA. Kaplan \& Sadock's Comprehensive text book of Psychiatry. Seventh Edition, Lippincott Williams \& Wilkins Co, 2005; 1: $1720-1729$.

12. Guyton AC, Hall JE. Textbook of Medical Physiology, 11st ed. Philadelphia; Elsevier Saunders Co. 2006; 73946.

13. Ibrahim EH, Kollef $\mathrm{MH}$. Using protocols to improve the outcomes of mechanically ventilated patients. Focus on wearing and sedation. Crit Care Clin 2001; 17(4): 989-1001.

14. Shapiro BA, Peruzzi WT. Respiratory care. In: Miller RD, ed: Anesthesia, 5th edition, New York: Churchill Livingstone 2000. 4: 2424.

15. Rivera, R. and J.F. Antognini, Perioperative drug therapy in elderly patients. J Am Soc Anesthesiol 2009; 110(5):1176-81. 
16. Lawrence VA, Cornell JE, Smetana GW. Strategies to Reduce Postoperative Pulmonary Complications after Noncardiothoracic Surgery: Systematic Review for the American College of PhysiciansStrategies to Reduce Postoperative Pulmonary Complications after Noncardiothoracic Surgery. Annals Int Med 2006. 144(8): 596-608.

17. [17] Hasukić Š. Pulmonary functions after laparoscopic and open cholecystectomy. Surg Endos Interven Techns 2002; 16(1): 163-165.

18. Karayiannakis A. Postoperative pulmonary function after laparoscopic and open cholecystectomy. British J Anaesthesia 1996; 77(4): 448-452.

19. Kravchenko I, Eberle L, Nesterkina M, Kobernik A. Anti-inflammatory and analgesic activity of ointment based on dense ginger extract (Zingiber officinale). J Herbmed Pharmacol 2019; 8(2): 126-132.

20. Karimi A, Mohammadi-Kamalabadi M, RafieianKopaei M, Amjad L, Salimzadeh I. Determination of antioxidant activity, phenolic contents and antiviral potential of methanol extract of Euphorbia spinidens Bornm (Euphorbiaceae). Trop J Pharmac Res 2016; 15(4):759-64.

21. Vaezi G, Tavasoli Z, S. R-B. Study on the different dosages of Elaeagnus angustifolia aqueous extract with and without morphine on the antinociceptive rate in mice. Research in Medicine. J Shahid Beheshti Uni $2011 ; 35(1): 27-33$.

22. Froushani SMA, Zarei L, Ghaleh HEG, Motlagh BM. Estragole and methyl-eugenol-free extract of Artemisia dracunculus possesses immunomodulatory effects. Avicenna J Phytomed 2016; 6(5): 526-534.

23. Abbasi N, Azizi Jalilian F, Abdi M, Saifmanesh M. A comparative study of the antimicrobial effect of Scrophularia striata Boiss. Extract and selective antibiotics against Staphylococcus aureus and Pesudomonas aeruginosa. J Med Plants 2007; 6(Suppl 1): $10-18+69$.

24. Bahmani, M., Khaksarian, M., Rafieian-Kopaei, M., Abbasi, N. Overview of the therapeutic effects of origanum vulgare and hypericum perforatum based on Iran's ethnopharmacological documents. J Clin Diagn Res 2018; 12(7): 1-4.

25. Shokri Z, Khoshbin M, Koohpayeh A, Abbasi N, Bahmani F, Rafieian-Kopaei, M, Beyranvand F. Thyroid diseases: Pathophysiology and new hopes in treatment with medicinal plants and natural antioxidants. Int J Green Pharmac 2018; 12(3): 473482.

26. Abbasi N, Mohammadpour S, Karimi E, Aidy A, Karimi P, Azizi M, et al. Protective effects of smyrnium cordifolium boiss essential oil on pentylenetetrazol-induced seizures in mice: Involvement of benzodiazepine and opioid antagonists. J Biol Regul Homeost Agents 2017; 31(3):683-689.

27. Tajbakhsh M, Karimi A, Tohidpour A, Abbasi N, Fallah F, Akhavan MM.The antimicrobial potential of a new derivative of cathelicidin from Bungarus fasciatus against methicillin-resistant Staphylococcus aureus. J Microbiol 2018; 56(2): 128-137.

28. Razmjoei D, zarei Z, Akbari M. Study of Ethnobutani Some Medicinal Plants in Abadeh, Fars Province. J Ecophysiol Crops 2015; 7 (3): 222-234.

29. Sharififaa F, MoharamKhani MR, Moaatar F, Babakhanlou P, Khodami M. Ethnobotanical Study of Medicinal Plants of Joopar Mountains of Kerman Province, Iran. J Kerman Uni Med Sci 2014; 21(1): 3751

30. Ganjali A, Khaksafidi A. Identification of Some pharmaceutical plant species in Zabol (Iran, Sistan and 
Baluchistan province) and Their application in traditional medicine. J Iran Islam Trad Med 2015; 6 (1): 89-96.

31. Khodayari H, Amani SH, Amiri H. Ethnobotanical study of Northeast of Khuzistan province. Med Plants Ecophytochem J 2013; 2(4):12-26.

32. Mirdalimi SZ, Heshmati GHA, Barani H. Ethnobotanical and ethnoecological survey on medicinal species (case study Kechik Rangelands in the Northeast Golestan Province). Indig Know 2015; 1(2): 129-154.

33. Khodayari H, Amani SH, Amiri H. Ethnobotanical study of Kichag city. Herb Med J 2013; 7(3):12-26.

34. Ghavam M, Jeihouni-Naeini H, Kianisalmi S. Indigenous and Traditional Knowledge of the Use of Medicinal Herbs in the Nain County. Native Iran Knowledge 2015; 2(4): 179-204.

35. Rojni H, Akbari F. Indigenous knowledge of the use of medicinal plants in the village of Erim, the area of the Thousand Jerim of Neka. The first national conference of medicinal herbs and aromatic herbs of Iran, Gonbad Kavoos 2017, 1: 2-4.

36. Ghasemi Pirbalouti A, Momeni M, Bahmani M. ETHNOBOTANICAL STUDY OF MEDICINAL PLANTS USED BY KURD TRIBE IN DEHLORAN AND ABDANAN DISTRICTS, ILAM PROVINCE, IRAN. Afr J Tradit Complement Altern Med 2013 $10(2): 368-385$.

37. Razmjoue D, Zarei Z, Armand R. Ethnobotanical Study (Identification, Medical Properties and How to Use) of some Medicinal Plants of Behbahan city of Khuzestan Province, Iran. J Med Plants 2018; 16(4): 33-49.

38. Abedi M., Panahi C., Sattariyan A., Habibi M. Study of Ethnobutane of Medicinal Plants in the Razujorgh County of North Khorasan Province. The first national conference of medicinal herbs and aromatic herbs of Iran, Gonbad Kavoos, May 1, 2017, Available in [conf.gonbad.ac.ir]

39. Sharififar F, Kouhpayeh A, Motaghi MM, AmirKhosravi A, Pou-Mohseninasab A. The reviews ethnobotany of medicinal plants city of Sirjan, Kerman Province. J Herbal Drugs 2010; 3:19-28.

40. Ranmanesh M, Najafi SH, Yousefi M. Ethnobotanical study of Medicinal Plants of Sistan region. J Herbal Drugs 2010; 2: 61-8.

41. Mozaffari Nejad as, Kamkar A, Giri A, Pourmahmoudi AA. Ethnobotany and folk medicinal uses of major trees and shrubs in Northern Iran. J Med Plants Res 2013; 7(7): 284-289.

42. Dolatkhahi M, Ghorbani Nahouji M, Mehrafarin A, Amininejad GHR, Dolatkhahi A. Ethnobutonic Study of Medicinal Plants in Kazeroon: Identification, Distribution and Traditional Costs. J Med Plants 2012; 11(2): 163-178.

43. Safa O, Soltanipoor MA, Rastegar S, Kazemi M, Nourbakhsh Dehkordi KH, Ghannadi A. An ethnobotanical survey on hormozgan province, Iran. Avicenna J Phytomed 2012; 3(1): 64-81

44. Procedural sedation in the acute care setting". Am Fam Physician. Jan 2005.

45. Jamshidi-Kia F, Lorigooini Z, Amini-Khoei $H$. Medicinal plants: past history and future perspective. J Herbmed Pharmacol 2018; 7(1):1-7.

46. Schulz V, Hansel R, Tyler V.E. Rational Phytotherapy. SpringerVerlag, Berlin and Heidelberg 2000; 101-104.

47. Bos R, Woerdenbag HJ, Van Putte, PMS, Hendriks H, Scheffer JJC. Seasonal variations of the essential oil, valerenic acid and derivatives, and velepotriates in valeriana officinalis roots and rhizomes, and the 
selection of plants suitable for phytomedicines. Planta Med 1998; 64: 143-147.

48. Vorbach E U, Gortelmeyer R, Bruning J. Therapie von insomnien: wirksameit und vertraglichkeit eines Baldrian-preparates. Psychopharmakotherapie 1996; 3: $109-115$

49. Ziegler G, Plotch M, Miettinen-Baumann A, Collet W. Efficacy and tolerability of valerian extract LI 156 compared with oxazepam in the treatment of nonorganic insomnia - a randomized, double-blind, comparative clinical study. Eur J Med Res 2002; 7: 480486

50. Gholamzadeh S, Zare S, Ilkhanipoor M. Anxiolytic effect of Echium amoenum during different treatment courses. Res J Biolog Sci 2008; 3(2):176-8.

51. Shafaghi B, Naderi N, Tahmasb L, Kamalinejad M. Anxiolytic effect of Echium amoenum L. in mice. Iranian J Pharmac Res 2010; 20:37-41.

52. Rabbani M, Sajjadi SE, Vaseghi G, Jafarian A. Anxiolytic effects of Echium amoenum on the elevated plus-maze model of anxiety in mice. Fitoterapia 2004; $1 ; 75(5): 457-64$.

53. Kyrou I, Christou A, Panagiotakos D, Stefanaki C, Skenderi K, Katsana K, Tsigos C. Effects of a hops (Humulus lupulus L.) dry extract supplement on selfreported depression, anxiety and stress levels in apparently healthy young adults: a randomized, placebo-controlled, double-blind, crossover pilot study. Hormones 2017; 16(2):171-80.

54. Shishehgar R, Rezaie A, Nazeri M. Study of sedation, pre-anesthetic and anti-anxiety effects of hop (Humulus lupulus L.) extract compared with diazepam in rats. J Animal Vet Adv 2012 11(14): 2570 - 2575.

55. Gulec M1, Ozkol H, Selvi Y, Tuluce Y, Aydin A, Besiroglu L, Ozdemir PG. Oxidative stress in patients with primary insomnia. Prog Neuropsychopharmacol Biol Psychiatry 2012; 1: 37(2): 247.

56. Bahmani M, Sarrafchi A, Shirzad H, Rafieian-Kopaei M. Autism: Pathophysiology and Promising Herbal Remedies. Current Pharmaceutical Design 2016; 22(3): $277-85$.

57. Shayganni E, Bahmani M, Asgary S, Rafieian-Kopaei M. Inflammaging and cardiovascular disease: Management by medicinal plants. Phytomed 2016; 23(11): 1119-26.

58. Hosseini Z, Lorigooini Z, Rafieian-Kopaei M, Shirmardi HA, Solati K. A review of botany and pharmacological effect and chemical composition of Echinophora species growing in Iran. Pharmacog Res 2017; 9(4): 305-312.

59. Moradi F, Sewell RDE, Lorigooini Z, Rafieian-Kopaei M. Immunosuppression-lipid Metabolism Interplay and Medicinal Plants in Atherosclerosis: A Review. Curr Pharmac Design 2018; 24:1-5.

60. Sarrafchi A, Bahmani M, Shirzad H, Rafieian-Kopaei M. Oxidative Stress and Parkinson's Disease: New Hopes in Treatment with Herbal Antioxidants. Curr Pharmac Design 2016; 22(2): 238-46.

61. Nazarian-Samani Z, Sewell RDE, Lorigooini Z, Rafieian-Kopaei M. Medicinal plants with multiple effects on diabetes mellitus and its complications: a systematic review. Curr Diab Rep 2018; 18: 72. 